\title{
Examining Levels of Job Burnout Among Teachers Working in Kosova in Terms of Different Variables
}

\author{
Assist. Prof. Dr. Sermin Turtulla
}

\begin{abstract}
This study examines job burnout levels of teachers teaching in primary and lower secondary schools in Kosova and changes in levels of teacher burnout according to demographic variables. Research data was collected using the Oldenburg Burnout Inventory (OLBI) and analysed using SPSS. Findings show moderate levels of exhaustion and disengagement for teachers teaching in primary and lower secondary schools; while, variables of gender, age, years of service, type of service, perceived socio-economic level, and marital status do not significantly affect burnout levels of teachers teaching in the southern part of Kosova, respectively Prizren.
\end{abstract}

Keywords: job burnout, teacher education, teacher disengagement, teacher exhaustion, Oldenburg Burnout Inventory.

\section{Introduction}

Burnout is a syndrome which affects individuals in their work environment and within specific job conditions causing them to feel psychological exhaustion and develop feelings of apathy. First described as a syndrome of emotional exhaustion, depersonalization, and reduced personal accomplishment by Maslach and Jackon (1985), burnout is also referred to as "an affective reaction" (Fernet, Guay, Senécal, and Austin, 2012:514); as a psychosocial discomfort experienced in a working environment (Montero-Marin et al, 2009); as a personality crisis with a right combination of stress, exhaustion and anxiety, which deteriorates health into illness by going beyond job-related one (Rudow, 1999); and as an outcome of being exposed to stress for too long by Shirom and Melamed (2006). Burnout's common symptom of exhaustion aligns it next to depression, making correct diagnosing a real accomplishment (Doohan, 1982). Stress and fatigue are mentioned alongside burnout because of their overlapping symptoms, especially its positive correlation with emotional exhaustion (Eisenstat, \& Felner, 1984). Further synthesis in burnout studies reveals that it can occur at any time in a life of a working individual and can develop unobtrusively until identified (Chen, Wu \& Wei, 2012). Although it can affect a wide spectre of individuals, studies show that people at most risk from burnout are those who are engaged in social work, such as nurses, medical staff, psychologists, counsellors, teachers, attorneys, police and social workers (Freudenberger, 1975; Maslach, \& Jackson, 1981; Schaufeli, \& Enzmann, 1998). Amongst the most vulnerable profession to both stress and burnout is the teaching profession (Rudow, 1999; Williams, 2011). Teachers are classified as a group prone to burnout due to their close and continuous contact with people namely students, parents, and administration (Maslach, \& Jackson, 1999; Fernet, Guay, Senécal, \& Austin, 2012). Further, studies on the relevant topic reveal an array of burnout symptoms which are classified into three major groups: physical (Belcastro, 1982; Rudow, 1999), psychological manifestations including emotional exhaustion, dissatisfaction, disappointment, loneliness, low morale and guilt (Doohan, 1982; Maslach, \& Jackson, 1985; Gil-Monte, 2012), and social symptoms with reduced work efficiency, sick leaves, absences from work, and early retirements (Maslach, \& Jackson, 1985; Rudow, 1999; Korczak, Huber, \& Kister, 2010; Korczak, Wastian, \& Schneider, 2012).

Similar concerns are also found in teacher burnout. Bauer, Stamm, Virnich, Wissing, Müller, Wirsching and Schaarschmidt (2006) identified burnout as a primary reason for driving teachers to premature retirement due to stress, exhaustion and depression. This distressful state within educational institutions inevitable affects learning process where teachers' performance deteriorates and they feel they cannot extend themselves to students' needs anymore. Teachers become depressed, hopeless, disappointed, and utterly helpless (Chen, Wu, \& Wei, 2012). Their relationship with students declines as teachers become uninterested in student learning (Rudow, 1999). Additionally, they withdraw from society or from socializing with peers developing cynicism towards colleagues, followed by de-motivation in developing professionally. Subsequently, this leads to deficit in teaching personnel, especially good teachers (Huston, 1989; Chang, 2013). 
Speculation on causes thirty years ago changed very little up to day, showing hapless victims of burnout manifest an array of symptoms depending on their respective personalities, attitude of people they serve, and organization they work in. Due to its complex nature, identifying causes that trigger burnout is a demanding enterprise. Research on this subject navigated in several directions including demographics, personality traits and organizational variables as the most common causes of teacher burnout (Nagy, \& Nagy, 1992). One of the most frequent routes of study is looking at demographic variables including gender, age, years of experience, education, and marital status. Teacher burnout has been reported to be dependent on certain demographic variables such as gender (Burke, \& Greenglass, 1989c). Contrary to deeply-rooted opinions that females should be more prone to burnout than males because of their innate caring nature, the results of first empirical studies showed the opposite (Maslach, \& Jackson, 1985). In the research carried out so far, gender variable made little difference when it came to levels of burnout, except that men scored higher on depersonalization level (Maslach, \& Jackson, 1985; Huston, 1989; Byrne, 1991). Similar findings are reported across other cultures (Bauer, Stamm, Virnich, Wissing, Müller, Wirsching, \& Schaarschmidt, 2006; Ozan, 2009; De Caroli, \& Sagone, 2012). While gender issue fails to generate any significant difference in burnout level among women and men, age proves the opposite (Maslach, \& Jackson, 1981; Byrne, 1991). The results on age and years of experience seem stable throughout nations with young teachers burning out more than older teachers, but some controversy is present here, too. For example, novice teachers in the States scored higher on emotional exhaustion and depersonalization than their older counterparts (Maslach, \& Jackson, 1981), and so did beginner teachers in Sweden as opposed to older teachers (Hultell, Melin, \& Gustavsson, 2013). The similar findings on emotional exhaustion were consistent only for university teachers in Canada while older teachers at primary levels, namely 40-50 of age difference had higher personal accomplishment than younger teachers (Byrne, 1991). In Italy, older Italian teachers expressed higher value for their students than they did for their freshmen colleagues (De Caroli, \& Sagone, 2012). They also showed lower depersonalization than middle aged groups (Huston, 1989). Controversial findings, though, were published in research done by Huston (1989) which revealed a possible explanation for inconsistency of age and burnout correlations.

Education impacts burnout in a sense that more education expects more money and if this is not met than it develops into burnout. On a far end, people who expect less and find more like the ones with less education are more satisfied with their job and correspondingly show less burnout (Maslach, \& Jackson, 1985). Teachers with college and postgraduate scored higher on emotional exhaustion than those without college, i.e. those in higher levels of administration reported less burnout indicating presence of specific burnout antecedents based on the academic status of teachers (Burke, \& Greenglass, 1989b). Personal preferences in career choice play a role in burnout, as reported by teachers in Cyprus. Those who were free to choose a profession they love experienced less burnout as compared to those who had no other choice (Ozan, 2009). An interesting combination was found between education and health for instance teachers with good health and educational success had lower initials levels of burnout, whereas those who had poor health and experienced strain during their education had higher initial levels of burnout (Hultell et al, 2013). In fact both good mental and physical health are negatively correlated to burnout (Hultell et al, 2013).

The variable of marital status reveals relatively homologues data in relation to burnout. Single and divorced individuals are more emotionally exhausted than married ones, whereas, married couples that do not have children report higher levels of burnout than couples who have (Maslach, \& Jackson, 1985). Family responsibilities show no significant difference on burnout levels as predetermined but quite surprisingly marriage and children alleviate levels of burnout, and one of explanations given is that when we get married we change our view on life and this is what diminishes feelings of burnout (Maslach, \& Jackson, 1985). Following their empirical study on role of family in burnout, Maslach and Jackson (1985) gave several possible explanations. First, people without offspring are more concerned with personal fulfilment and satisfaction and thus are more prone to recurring disappointment. Second, family is seen as an emotional haven where depleted resources are recharged again and third, family life equips individuals in solving inter-social conflicts. The significance of family role in combating burnout is emphasized by other researchers alike (Bauer et al, 2006) on whose resource list family is one of the strongest tools in fighting off burnout (Braunstein-Bercovitz, 2013). The coping strategies that fight burnout have their share of debate, where certain dimensions of burnout are seen as efforts of coping rather than expressions of symptoms (Burke, \& Greenglass, 1989c; Eisenstat, \& Felner, 1984). So far, studies on burnout have identified a number of ways to combat this psychological state, proposing a combination of personal empowerment, social support, and reduced workload as preventions, although less workload failed to influence burnout levels (Braunstein-Bercovitz, 2013). Other scholars proposed a dual action of creating a stimulating environment while cutting down on stressors at work (Eisenstat, \& Felner, 1984). 


\section{Methodology}

The research on this paper has been carried out through a correlated survey method and it is based on descriptive method of research. Data are analysed using independent sample t-test (Köklü, Büyüköztürk, Bökeoğlu, 2007; Balcı, 2007; Büyüköztürk, 2010), frequency and percentage method, analysis of variance (ANOVA) and Scheffe Test. Disengagement and exhaustion levels are examined in relation to job burnout levels of teachers teaching in primary and lower secondary schools in Prizren. Second, demographic characteristics of teachers such as gender, age, years of service, type of service, perceived socio-economic level, and marital status are tested to find out if they present a factor for disengagement and exhaustion of job burnout.

\section{Participants}

In its initial stage, research was carried out on 531 teachers teaching in primary and lower secondary schools in Prizren during 2013/14 academic year through sampling method from the total of 17468 teachers in Kosova. According to general number designation in order to determine a sample population we took into consideration Gay's (1996) table developed to designate a sample group based on a general number of population.

A careful examination of findings related to a research sample population, shows that from the total of participants, 379 are female $(\% 71,4), 152$ are male $(\% 28,6)$. Out of these 59 participants belong to $26-30$ age group $(\% 11,1), 52$ participants to $31-35$ age group (\%9,8), 53 participants to $36-40$ age group (\%10), 63 participants to $41-45$ age group (\%11,9), 98 participants to $46-50$ age group (\%18,5), 72 participants to $51-55$ age group $(\% 13,6), 73$ participants to $56-60$ age group $(\% 13,7)$ and 61 participants to 60 age group and above $(\% 11,5)$. From these, $49(9,2 \%)$ participants have $1-5$ years of service in teaching, $72(13,6 \%)$ participants have $6-10$ years of service in teaching, $67(12,6 \%)$ participants have 11-15 years of service in teaching, $59(11,1 \%)$ participants have $16-20$ years of service in teaching, and $284(53,5 \%)$ participants have over $21+$ years of service in teaching. According to type of service, $237(44,6 \%)$ participants are primary education teachers, and $294(55,4 \%)$ participants are subject-focused teachers. $54(10,2 \%)$ participants have low socio-economic level, $397(74,8 \%)$ participants have moderate socio-economic level, and $80(15,1 \%)$ participants have high socio-economic level. Out of these $467(87,9 \%)$ participants are married, and 64 (12,1\%) participants are single.

\section{Data Collection Instruments}

During the research procedure, two types of instruments were used for collecting data. The first one is a personal information form developed by the author and the second one is the Oldenburg Burnout Inventory for measuring burnout. The personal information form has several questions about personal information of participants including gender, age, years of service, type of service, perceived socio-economic level, and marital status. The second data collection instrument is the Oldenburg Burnout Inventory (OLBI) developed in 1998 by Demerouti, Bakker, Nachreiner and Schaufeli as an alternative measurement (Demerouti, Bakker, Nachreiner, \& Schaufeli, 2001) to Maslach's MBI. The joint undertaking of Dutch and German authors of OLBI tried to surmount drawbacks of previous instruments and opted for dualism in burnout. The grounds of their argument lie on a JD-R model, a Job Demands-Resources model which suggests that employees who face high demands in their jobs but have run out of available coping resources will develop burnout (Demerouti et al, 2001). After observing that the $\mathrm{MBI}$ instrument has a wording issue, namely grouping the same worded items in specific dimensions, this group of researchers in their two-factor model of exhaustion and disengagement used positive and negative worded items interchangeably (Demerouti et al, 2001). Two dimensions of OLBI exhaustion and disengagement encompass wider burnout symptoms, because the dimension of exhaustion is not limited only to emotional fatigue but covers also cognitive, physical, and mental weariness.

Oldenburg Burnout Inventory instrument comprises of sixteen statements which are divided into eight items in disengagement dimension and eight items in exhaustion. For both dimensions, four items are phrased negatively, and four items are phrased positively. This dual model of burnout with exhaustion and withdrawal is accredited as the reliable method for testing job burnout (Demerouti, Bakker, Nachreiner, \& Schaufeli, 2001). The reliability coefficients for OLBI is .71 for exhaustion and .73 for disengagement. The OLBI instrument was translated from English into Albaninan language by the author.

\section{Findings}


In terms of exhaustion and disengagement levels, findings show that $7 \%$ of teachers have low levels of exhaustion, 84.9 $\%$ moderate and $8.1 \%$ have high levels of exhaustion. While $10.5 \%$ of teachers have low levels of disengagement, 83.2 $\%$ have moderate and $6.3 \%$ have high levels of disengagement.

According to gender variable, disengagement level mean in females is $(\bar{x}=14,36)$ standard deviation $(S=4,02)$ and mean in males is $(\bar{x}=15,11)$ and standard deviation $(S=3,36)$. While exhaustion level mean in females is $(\bar{x}=16,39)$ standard deviation $(S=4,12)$ and mean level in males is $(\bar{x}=16,74)$ and standard deviation $(S=3,59)$. In order to determine if there is a significant difference between these scores a t-test was administered and findings for disengagement $\left(t_{(529)}=-2,02\right.$, $P>0,05)$, and for exhaustion ( $\left.t_{(529)}=-0,901, P>0,05\right)$ in terms of gender variable show no significant difference in levels of burnout as shown in table 1 .

\begin{tabular}{|c|c|c|c|c|c|c|c|c|c|c|}
\hline & & & & t-test f & quality of $m$ & & & & $\begin{array}{l}\text { Leven } \\
\text { equalit } \\
\text { varian }\end{array}$ & Test for \\
\hline Scale & Dimensions & Gender & $\mathrm{N}$ & Mean & $\begin{array}{l}\text { Std. } \\
\text { Deviation }\end{array}$ & df & $t$ & $\mathrm{P}$ & $\mathrm{F}$ & $\mathrm{P}$ \\
\hline \multirow{4}{*}{$\begin{array}{l}\text { Job } \\
\text { Burnout }\end{array}$} & \multirow{2}{*}{ Disengagement } & Female & 379 & 14,36 & 4,02 & \multirow{2}{*}{529} & \multirow{2}{*}{$-2,02$} & \multirow{2}{*}{0} & \multirow{2}{*}{0,001} & \multirow{2}{*}{0,988} \\
\hline & & Male & 152 & 15,11 & 3,36 & & & & & \\
\hline & \multirow{2}{*}{ Exhaustion } & Female & 379 & 16,39 & 4,12 & \multirow{2}{*}{529} & \multirow{2}{*}{$-0,901$} & \multirow{2}{*}{0,4} & \multirow{2}{*}{0,197} & \multirow{2}{*}{0,657} \\
\hline & & Male & 152 & 16,74 & 3,59 & & & & & \\
\hline
\end{tabular}

Table 1. Disengagement and exhaustion means according to gender variable

Disengagement and exhaustion levels of participants according to age variable show exhaustion level mean for 26-30 age group teachers $(\bar{x}=16,25)$ standard deviation $(S=3,01) ; 31$-35 age group teachers $(\bar{x}=16,22)$ standard deviation $(S=$ $3,22) ; 36-40$ age group teachers $(\bar{x}=16,36)$ standard deviation $(S=2,48) ; 41-45$ age group teachers $(\bar{x}=16,71)$ standard deviation $(S=3,23)$; $46-50$ age group teachers $(\bar{x}=16,27)$ standard deviation $(S=3,68) ; 51-55$ age group teachers $(\bar{x}=$ $16,20)$ standard deviation $(S=3,23) ; 56-60$ age group teachers $(\bar{x}=16,37)$ standard deviation $(S=3,07)$, and exhaustion level mean for $61+$ age group teachers $(\bar{x}=17,73)$ and standard deviation $(S=7,65)$. While findings for disengagement level mean for $26-30$ age group teachers $(\bar{x}=13,98)$ standard deviation $(S=3,05) ; 31-35$ age group teachers $(\bar{x}=14,98)$ standard deviation $(S=3,51) ; 36-40$ age group teachers $(\bar{x}=14,20)$ standard deviation $(S=2,92) ; 41-45$ age group teachers $(\bar{x}=14,57)$ standard deviation $(S=3,19) ; 46-50$ age group teachers $(\bar{x}=14,48)$ standard deviation $(S=3,29) ; 51-55$ age group teachers $(\bar{x}=14,37)$ standard deviation $(S=2,77) ; 56-60$ age group teachers $(\bar{x}=14,78)$ standard deviation $(S=$ $3,78)$, and disengagement level mean for $61+$ age group $(\bar{x}=15,35)$ and standard deviation $(S=7,00)$ as shown in table 2 . In order to determine if there is a significant difference between these scores an F-test is administered and findings for disengagement $\left(F_{(7-523)}=, 776, P>0,05\right)$, and for exhaustion $\left(F_{(7-523)}=1,057, P>0,05\right)$ in terms of age variable show no significant difference in levels of burnout as given below in table 3 . 


\begin{tabular}{|c|c|c|c|c|}
\hline & & $\mathrm{N}$ & Mean & Std. Deviation \\
\hline \multirow[t]{9}{*}{ Disengagement } & $26-30$ age & 59 & 13,98 & 3,05 \\
\hline & $31-35$ age & 52 & 14,98 & 3,51 \\
\hline & $36-40$ age & 53 & 14,20 & 2,92 \\
\hline & 41-46 age & 63 & 14,57 & 3,19 \\
\hline & $46-50$ age & 98 & 14,48 & 3,29 \\
\hline & $51-55$ age & 72 & 14,37 & 2,77 \\
\hline & $56-60$ age & 73 & 14,78 & 3,78 \\
\hline & $61+$ & 61 & 15,35 & 7,00 \\
\hline & Total & 531 & 14,58 & 3,86 \\
\hline \multirow[t]{9}{*}{ Exhaustion } & $26-30$ age & 59 & 16,25 & 3,01 \\
\hline & $31-35$ age & 52 & 16,22 & 3,22 \\
\hline & $36-40$ age & 53 & 16,36 & 2,48 \\
\hline & 41-45 age & 63 & 16,71 & 3,23 \\
\hline & $46-50$ age & 98 & 16,27 & 3,68 \\
\hline & $51-55$ age & 72 & 16,20 & 3,23 \\
\hline & $56-60$ age & 73 & 16,37 & 3,07 \\
\hline & $61+$ & 61 & 17,73 & 7,65 \\
\hline & Total & 531 & 16,50 & 3,98 \\
\hline
\end{tabular}

Table 2. Disengagement and exhaustion means according to age variable

\begin{tabular}{llccccc}
\hline \hline & & Sum of Squares & $\mathrm{df}$ & Mean Square & $\mathrm{F}$ & Sig. \\
\hline Disengagement & Between Groups & 81,03 & 7 & 11,575 &, 776 &, 608 \\
& Within Groups & 7804,88 & 523 & 14,923 & & \\
& Total & 7885,91 & 530 & & & \\
\hline Exhaustion & Between Groups & 116,90 & 7 & 16,700 & 1,057 &, 391 \\
& Within Groups & 8266,32 & 523 & 15,806 & & \\
& Total & 8383,22 & 530 & & & \\
\hline \hline
\end{tabular}

Table 3. Disengagement and exhaustion F-test findings according to age variable

Years of service variable findings reveal disengagement level mean for teachers working 1-5 years $(\bar{x}=14,81)$ standard deviation $(S=2,66)$; for teachers working $6-10$ years $(\bar{x}=14,52)$ standard deviation $(S=3,39)$; for teachers working 11-15 years $(\bar{x}=14,02)$ standard deviation $(S=2,70)$; for teachers working $16-20$ years $(\bar{x}=14,15)$ standard deviation $(S=3,45)$; and teachers with more than 21 years of service $(\bar{x}=14,77)$ standard deviation $(S=4,41)$. While findings show exhaustion level mean for teachers working 1-5 years $(\bar{x}=16,44)$ standard deviation $(S=2,80)$; for teachers working $6-10$ years $(\bar{x}=$ $16,30)$ standard deviation $(S=2,99)$; for teachers working $11-15$ years $(\bar{x}=16,02)$ standard deviation $(S=3,02)$; for teachers working $16-20$ years $(\bar{x}=16,25)$ standard deviation $(S=3,38)$; and teachers with more than 21 years of service $(\bar{x}=16,71)$ standard deviation $(S=4,62)$ as shown in table 4. F-test findings for disengagement $\left(F_{(4-526)}=, 755, P>0,05\right)$, and for exhaustion $\left(F_{(4-526)}=, 546, P>0,05\right)$ in terms of years of service variable show no significant difference in levels of burnout as shown in table 5 . 


\begin{tabular}{lllcc} 
& & $\mathrm{N}$ & Mean & Std. Deviation \\
\hline Disengagement & $1-5$ year & 49 & 14,8190 & 2,66676 \\
& 6-10 year & 72 & 14,5245 & 3,39501 \\
& $11-15$ year & 67 & 14,0271 & 2,70937 \\
& $16-20$ year & 59 & 14,1564 & 3,45054 \\
& $21+$ & 284 & 14,7763 & 4,41093 \\
\hline \multirow{2}{*}{ Exhaustion } & Total & 531 & 14,5827 & 3,85734 \\
\hline & 1-5 year & 49 & 16,4428 & 2,80454 \\
& 6-10 year & 72 & 16,3032 & 2,99466 \\
& $11-15$ year & 67 & 16,0283 & 3,02734 \\
& $16-20$ year & 59 & 16,2534 & 3,38499 \\
& $21+$ & 284 & 16,7157 & 4,62932 \\
& Total & 531 & 16,4965 & 3,97711 \\
\hline \hline
\end{tabular}

Table 4. Disengagement and exhaustion means according to years of service variable

\begin{tabular}{llccccc}
\hline \hline & & Sum of Squares & df & Mean Square & F & Sig. \\
\hline Disengagement & Between Groups & 45,028 & 4 & 11,257 &, 755 &, 555 \\
& Within Groups & 7840,884 & 526 & 14,907 & & \\
& Total & 7885,912 & 530 & & & \\
\hline Exhaustion & Between Groups & 34,653 & 4 & 8,663 &, 546 &, 702 \\
& Within Groups & 8348,565 & 526 & 15,872 & & \\
& Total & 8383,218 & 530 & & & \\
\hline \hline
\end{tabular}

Table 5. Disengagement and exhaustion F-test findings according to years of service variable

Type of service variable findings show disengagement level mean for primary education teachers $(\bar{x}=14,4)$ standard deviation $(S=4,51)$ and for subject-focused teachers $(\bar{x}=14,72)$ and standard deviation $(S=3,23)$. While findings reveal exhaustion level mean for primary education teachers $(\bar{x}=16,3)$ standard deviation $(S=4,78)$ and for subject-focused teachers $(\bar{x}=16,65)$ and standard deviation $(S=3,17)$. T-test findings for disengagement $\left(t_{(529)}=-0,96, P>0,05\right)$, and for exhaustion $\left(t_{(529)}=0,99, P>0,05\right)$ in terms of type of service variable show no significant difference in levels of burnout as given in table 6 .

\begin{tabular}{|c|c|c|c|c|c|c|c|c|c|c|}
\hline \multirow[b]{2}{*}{ Scale } & \multirow[b]{2}{*}{ Dimensions } & \multirow[b]{2}{*}{$\begin{array}{l}\text { Type of } \\
\text { service }\end{array}$} & \multirow[b]{2}{*}{$\mathrm{N}$} & \multicolumn{5}{|c|}{ T-test for Equality of Means } & \multicolumn{2}{|c|}{$\begin{array}{l}\text { Levene's Test for } \\
\text { Equality of } \\
\text { Variances }\end{array}$} \\
\hline & & & & Mean & $\begin{array}{l}\text { Std. } \\
\text { Deviation }\end{array}$ & df & $\mathrm{t}$ & $\mathrm{P}$ & $\mathrm{F}$ & $P$ \\
\hline Job & Disengagement & Primary & 237 & 14,4 & 4,51 & 529 & $-0,96$ & 0,339 & 0,92 & 0,762 \\
\hline
\end{tabular}




\begin{tabular}{|c|c|c|c|c|c|c|c|c|c|c|}
\hline \multirow[t]{3}{*}{ Burnout } & & Other & 294 & \multirow{2}{*}{$\begin{array}{c}14,72 \\
16,3\end{array}$} & 3,23 & \multirow[b]{2}{*}{529} & \multirow[b]{2}{*}{$-0,99$} & \multirow{3}{*}{0,321} & \multirow{2}{*}{0,596} & \multirow{2}{*}{0,44} \\
\hline & \multirow{2}{*}{ Exhaustion } & Primary & 237 & & 4,78 & & & & & \\
\hline & & Other & 294 & 16,65 & 3,17 & & & & & \\
\hline
\end{tabular}

Table 6. Disengagement and exhaustion means according to type of service variable

The perceived socioeconomic level variable shows disengagement level mean for teachers with low socioeconomic level $(\bar{x}=15,09)$ standard deviation $(S=3,06)$, for teachers with moderate socioeconomic level $(\bar{x}=14,51)$ standard deviation $(S=4,14)$, and for teachers with high socioeconomic level $(\bar{x}=14,61)$ and standard deviation $(S=2,75)$. While findings reveal exhaustion level mean for teachers with low socioeconomic level $(\bar{x}=16,97)$ standard deviation $(S=3,10)$, for teachers with moderate socioeconomic level $(\bar{x}=16,45)$ standard deviation $(S=4,22)$, and for teachers with high socioeconomic level $(\bar{x}=16,43)$ and standard deviation $(S=3,19)$ given below in table 7 . F-test findings for disengagement $\left(F_{(2-528)}=, 548, P>0,05\right)$, and for exhaustion $\left(F_{(2-528)}=, 425, P>0,05\right)$ in terms of socioeconomic level variable show no significant difference in levels of burnout as shown in table 8.

\begin{tabular}{llccc} 
& & $\mathrm{N}$ & Mean & Std. Deviation \\
\hline Disengagement & Low & 54 & 15,09 & 3,06 \\
& Moderate & 397 & 14,51 & 4,14 \\
& High & 80 & 14,61 & 2,75 \\
& Total & 531 & 14,58 & 3,86 \\
\hline Exhaustion & Low & 54 & 16,97 & 3,10 \\
& Moderate & 397 & 16,45 & 4,22 \\
& High & 80 & 16,43 & 3,19 \\
& Total & 531 & 16,50 & 3,98 \\
\hline \hline
\end{tabular}

Table 7. Disengagement and exhaustion means according to perceived socio-economic level variable

\begin{tabular}{llccccc}
\hline & & Sum of Squares & $\mathrm{df}$ & Mean Square & $\mathrm{F}$ & Sig. \\
\hline Disengagement & Between Groups & 16,335 & 2 & 8,168 &, 548 &, 578 \\
& Within Groups & 7869,577 & 528 & 14,905 & & \\
& Total & 7885,912 & 530 & & & \\
\hline Exhaustion & Between Groups & 13,481 & 2 & 6,741 &, 425 &, 654 \\
& Within Groups & 8369,737 & 528 & 15,852 & & \\
& Total & 8383,218 & 530 & & & \\
\hline \hline
\end{tabular}

Table 8. Disengagement and exhaustion F-test findings according to perceived socio-economic variable

And the variable of marital status findings show disengagement level mean for married teachers $(\bar{x}=14,64)$ standard deviation $(S=3,97)$ and for single teachers $(\bar{x}=14,09)$ and standard deviation $(S=2,79)$. While findings reveal exhaustion level mean for married teachers $(\bar{x}=16,54)$ standard deviation $(S=4,11)$ and for single teachers $(\bar{x}=16,12)$ and standard deviation $(S=2,79)$. T-test is administered and findings for disengagement $\left(t_{(529)}=1,07, P>0,05\right)$, and for exhaustion $\left(t_{(529)}=0,79, P>0,05\right)$ in terms of marital status variable show no significant difference in levels of burnout as given in table 9. 


\begin{tabular}{|c|c|c|c|c|c|c|c|c|c|c|}
\hline \multirow[b]{2}{*}{ Scale } & \multirow[b]{2}{*}{ Dimensions } & \multirow[b]{2}{*}{$\begin{array}{l}\text { Marital } \\
\text { status }\end{array}$} & \multirow[b]{2}{*}{$\mathrm{N}$} & \multicolumn{5}{|c|}{ T-test for Equality of Means } & \multicolumn{2}{|c|}{$\begin{array}{l}\text { Levene's Test for } \\
\text { Equality of } \\
\text { Variances }\end{array}$} \\
\hline & & & & Mean & $\begin{array}{l}\text { Std. } \\
\text { Deviation }\end{array}$ & $d f$ & $\mathrm{t}$ & $P$ & $\mathrm{~F}$ & $P$ \\
\hline \multirow{4}{*}{$\begin{array}{l}\text { Job } \\
\text { Burnout }\end{array}$} & \multirow{2}{*}{ Disengagement } & Married & 467 & 14,649 & 3,97 & \multirow{2}{*}{529} & \multirow{2}{*}{1,07} & \multirow{2}{*}{0,281} & \multirow{2}{*}{1,36} & \multirow{2}{*}{0,243} \\
\hline & & Single & 64 & 14,09 & 2,79 & & & & & \\
\hline & \multirow{2}{*}{ Exhaustion } & Married & 467 & 16,54 & 4,11 & \multirow{2}{*}{529} & \multirow{2}{*}{0,79} & \multirow{2}{*}{0,431} & \multirow{2}{*}{1,44} & \multirow{2}{*}{0,23} \\
\hline & & Single & 64 & 16,12 & 2,79 & & & & & \\
\hline
\end{tabular}

Table 9. Disengagement and exhaustion means according to marital status variable

\section{Results}

Amidst scarce research conducted in Kosova, this is the first research of this kind to be undertaken in this country. Findings gave the following results: teachers teaching in Kosova, respectively in Prizren show moderate levels of disengagement and exhaustion; female teachers show higher levels of exhaustion, but male teachers show both higher levels of disengagement and exhaustion; disengagement and exhaustion levels of teachers increase with age; disengagement and exhaustion levels of teachers change according to their years of service, where especially exhaustion levels correlate to an increase in years of teaching; disengagement and exhaustion levels of subject-focused teachers are higher as compared to primary education teachers; teachers with perceived low socioeconomic level show higher levels of disengagement and exhaustion, and married teachers show higher levels of disengagement and exhaustion as compared to single ones.

\section{Discussion}

Presently, teaching system in Kosova is in the process of finding a new identity for itself, in one of the poorest countries in the South-eastern Europe, where $75 \%$ of its labour force is younger than 35 years of age (Ministria e Arsimit, Shkencës dhe Teknologjisë [MASHT], 2011); however, $56.9 \%$ are within an employment age and only $28.7 \%$ of these are employed (MASHT, 2006). According to the government report of Ministry of Education, Science and Technology in Kosova, the country needs to accommodate 20.000 jobs for its nation, annually. This $24.66 \%$ surge of school-age nation requires reforms and strategic planning in order to follow current and future market needs of the country. Consequently, a reliable education system and dependable teaching personnel have significant role in producing a qualified workforce. The understated objective of this research, then, addresses a national need in advancing the quality of teaching (MASHT, 2011) through improving cognitive and psychological abilities of teachers. Indirectly, the study responds to the international need of analysing burnout in cultural and national perspectives (Schaufeli, \& Enzmann, 1998), with a heightened focus on conducting research in non-English speaking countries (Rudow, 1999). Therefore the present research on burnout levels of Kosovar teachers endorses the country's current education plan of advancing professional development of teachers. There is a considerable study done on market research but study is scarce in education research, and particularly in the aspect of teaching personnel in the country (author et al, 2012). Because teaching staff is a major contributor to efficient teaching and quality learning, we need to give to it a special care, ensuring both mental and psychological wellbeing of its members.

Teachers teaching in Kosova show moderate levels of disengagement and exhaustion. This finding is in line with other results from around the world. Although percentages change from country to country, burnout has plagued teachers in the States (Maslach, \& Jackson, 1985; Huston, 1989), in Canada (Byrne, 1991), in China (Yu, 2005; Zhong, \& Ling, 2014), Cyprus (Ozan, 2009), Spain (Cano-Garcia, Padilla-Munoz, \& Carrasco-Ortiz, 2005), Germany (Bauer et al, 2006), Italy (De Caroli, \& Sagone, 2012), Serbia (Nenadović, Janković, Katanić, Đokić-Pješčić, Malešević, Radulović, Nenadović, \& Grbić, 2013), and Sweden (Hultell, Melin, \& Gustavsson, 2013). The staggering $90 \%$ of teachers report moderate to high levels of exhaustion and disengagement. The causes of teacher burnout in Kosova are to be found on both personal and social level. On personal level teachers have to balance their personal ideals with individual possibilities. Teachers in Kosova showed commitment to their nation and teaching, by attaining their professional identity during perilous pre-war years 
(Slinn, 2008). Yet after surviving war, exhaustion followed having to fight for daily living in post war Kosova. Although they loved their profession, this left them with little time for professional development and consequently drove them into challenging situations in classrooms. On social level, teachers personal drives are rarely harmonized with social strive. Social mismatch of these needs and requests are reflected from government officials to school principals, students and parents. Changes in education have given rise to shifts in power relations between students and teachers. Now students' sayings are valued over teacher's one. Thus, teachers find themselves in an unfamiliar situation, unsure on how to proceed with teaching, because student's newly found boorish freedom is taking a toll on discipline issues, which is the most sensitive issue for teachers. On top of this, there is a high level of national corruption present in every aspect of society including education. The overall lingering expression that there is nothing that can be done to change this position has made teachers join in the general apathy of national dissatisfaction. This has hindered them from taking any sort of action in changing their present situation. Moderate levels of burnout identified in teachers in Kosova might have a direct correlation with poor quality of learning process presently highlighted in the country.

Female teachers show higher levels of exhaustion but male teachers show higher levels of both exhaustion and disengagement. Findings are along the lines with other studies as regards gender issue (Maslach, \& Jackson, 1985; Huston, 1989; Byrne, 1991; Ozan, 2009). Although gender variable makes little difference to burnout levels still, women continue to be associated with dimension of exhaustion, and men with that of disengagement. The reasoning that Maslach and Jackson (1985) give regarding this is a socially-rooted belief that women get more emotionally involved with people as compared to men. The similar belief is held also for women in Kosova. In addition, there are additional stereotyping beliefs associated with Kosovar female believing that they are pillars of a family. They are caring mothers who silently endure life difficulties and try to give the best to their children. This female model is transferred to a female teacher, whom Kosovar society sees as second mother to her school children. Kosovar female teacher is expected to express the same caring attitude towards her students as she does towards her children. Naturally, she assumes her role wholeheartedly and tries to do her best. Reasonably, displaying more and more sympathetic attention towards dozens and dozens of students is energy consuming and this leaves female teachers more exhausted, but also more satisfied with their work because of the sisterhood environment they share at school (Burke, \& Greenglass, 1989c). The present results are in line with findings where male teachers show higher disengagement and exhaustion levels (Burke, \& Greenglass, 1989c; Van Horn, Schaufeli, Greenglass, \& Burke, 1997; Zhong, \& Ling, 2014). Some of possible explanations again might be found in social beliefs about gender affiliation towards certain jobs. Thus, teaching is primarily populated with females (Burke, \& Greenglass, 1989c), as evident in our sample group statistics were $71,4 \%$ of primary and lower secondary school teachers are females. However, the gender balance seems to shift towards males in accordance to level of education, i.e. $73,1 \%$ of novice teachers that attend Faculty of Education are females; however, there are very few female university professors (MASHT, 2011). Consequently, male teachers in primary and lower secondary schools might encounter difficulties in adjusting to a job originally thought to be a female profession. As a result, male coping resources might come in action in form of dealing more with discipline issues (Burke, \& Greenglass, 1989c; Van Horn et al, 1997) which corresponds to their gender status, triggering thus more student reaction and less learning effectiveness (Huston, 1989). Extra work in managing discipline in the class and low opinion about themselves might be a possible explanation for high levels of burnout in male teachers (De Caroli, \& Sagone, 2012).

Additionally, older teachers show increase in levels of exhaustion and disengagement as compared to younger teachers, the age curve is not straightforward. Findings show an increase of exhaustion levels for teachers in their early 40's and after their 60's, while the disengagement curve fluctuates between early 30's, early 40's, and from late 50's above. Such fluctuation is best explained by Huston (1989), who observed that teachers are susceptible to burnout at any age, predetermined only by actual intensity and time of their disillusionment. Possible causes for such a disappointment of teachers in post-war Kosova should be searched in the country's social policy system concerned with job availability and retirement benefit. Most of graduates end up teaching because of a limited number of available jobs in the market. In fact, in a country where $39.7 \%$ of its population is unemployed, teaching is seen as one of few professions that can secure a stable contract (MASHT, 2006). According to 2004 statistics, presented in the action plan for employment of youth in Kosova published by Ministry of Education, Science and Technology in 2006, out of $28.7 \%$ of its employed nation more than $10 \%$ work in education only. However due to lack of employment opportunities, a teaching job is more a forced-choice option rather than a free-will preference.

As with the age variable, years of service prove to predetermine teacher burnout. Our findings are contrary to findings from elsewhere for instance the States, Canada, Sweden and Italy (Maslach, \& Jackson, 1981; Hultell, Melin, \& Gustavsson, 
2013; Byrne, 1991; De Caroli, \& Sagone, 2012) where novice teachers are more burned out than senior teachers. However, our results are in line with Huston's (1989) research which revealed an explanation that burnout can begin at later stages of teaching also, correlating to their disillusionment. For Kosovar teachers possible reasons for their frustration are to be found in the education system of the country. In fact, an aspect that needs to be taken into consideration when analysing the variable of service years is that senior teachers with higher levels of exhaustion belong to a group who have taught in parallel education system and have experienced war. They have maintained high spirit throughout two decades, seeing independence as a new beginning for the country and its nation. Freedom, however, failed to restore their professional respect, or sustain economic security. For years, these teachers had gone accustomed to teaching with old methodology and out-dated material. However, rapid changes after war in form of innovative teaching strategies, latest technologies, and new economic requirements found them poorly equipped for this market, with obsolete knowledge and abilities that needed to be refreshed and improved (MASHT, 2011). Developing professionally alongside managing teaching in afterwar Kosova with large classes, poorly disciplined students, unsupportive administration, weakly equipped schools, disrespectful parents and especially, high levels of corruption prove to be a challenge. Teaching under these circumstances and not seeing any improvement or change for better might be a possible reason for senior teachers to get disillusioned at this stage of their career (Boles, Dean, Ricks, Short, \& Wang, 2000). Subsequently, this diminishes teachers' incentive to take moral and ethical action towards professional improvements, which are not accredited by respective authorities, or financially stimulated. Gradually these signs have collected over time in senior teachers who teach more than twenty years, and developed into burnout (Byrne, 1999; Rudow, 1999).

Disengagement and exhaustion levels of subject-focused teachers are higher when compared to primary education teachers. These findings echo the significance of grades teachers teach (Burke, \& Greenglass, 1989a; Van Horn et al, 1997; Byrne, 1999). A possible explanation for this is to be found in teacher satisfaction. Primary education teachers who teach young learners get more satisfaction from teaching because children at this age are better learners and more disciplined students than older learners, as observed by Burke and Greenglass (1989a) research which showed that primary school teachers are less burned out despite having more work, or being longer in the profession. Thus, teachers who see results in their teaching, and have higher self-appreciation are less likely to have burnout (De Caroli, \& Sagone, 2012).

Teachers with perceived low socioeconomic level show higher levels of exhaustion and disengagement. This variable best reflects teachers' poor situation in Kosova, as relates to their both social and economic status (MASHT, 2006) giving a possible explanation for correlation of burnout with low socioeconomic status, which can be reflected in dual identity of Kosovar teachers. Positive correlation of exhaustion with low socioeconomic situation has its roots in pre-war Kosova, where teachers have long been overworked in trying to subsist by working in other jobs besides teaching. This situation began in 1991 when Serbian authorities who were governing the country then, banished Albanian teachers and closed down Albanian schools. Urged by their need to continue and educate children, Albanian teachers formed a parallel education system throughout Kosova and kept on teaching undercover until 1999 when the war began (Slinn, 2008). For over eight years teachers taught voluntarily, but had to look for an additional paid work in order to support themselves and their families. So, you could easily find physics teachers running computer shops, biology teachers working as taxi-drivers, primary teachers managing a kindergarten, or English teachers working as translators and office assistants. Putting up with a second job, considerably reduced their capacity to develop professionally due to exhaustion and time lost in other undertakings. More than two decades of academic seclusion left teachers professionally impaired. Later on more energy and more time was needed to replenish their resources and teaching skills and despite their earnest desire to improve teaching and offer better education to learners, teachers of post-war Kosova are still unable to keep pace with new trends in their subject-matter, follow constantly changing technology (MASHT, 2006; 2011), and digest the surge of diverse knowledge that students possess. Consequently, feelings of exhaustion, disappointment (Demerouti, Bakker, Nachreiner, \& Ebbinghaus, 2002), and low self-efficacy follow amounting to teacher burnout (Fernet, Guay, Senécal, \& Austin, 2012; Hultell, Melin, \& Gustavsson, 2013).

At last, married teachers show higher levels of disengagement and exhaustion as compared to single ones. The marriage variable results are contrary to outcomes from other countries, such as the States and Germany, (Maslach, \& Jackson, 1985; Bauer et al, 2006; Braunstein-Bercovitz, 2013). Although reasons listed by these researchers such as support from partners and a more stable view that married couples have on life which runs contrary to a state of burnout are valid for Kosovar couples too, results obtained from this study show a slightly different story. One of the explanations might be because the socio-economic situation in the country affects married couples more than singles, where the former with their 
family and children have more people to feed and cater for. In addition, most of married couples live in a community with in-laws where traditional domestic customs of looking after the house and family have prevailed, leaving little space for couple privacy as a prerequisite for partner support. Although a number of couples that move out from their in-laws is in the increase, still they are outnumbered, and those who decide to move out usually go on rent, which is an additional financial burden on a couples' budget. This constant financial struggle is a temporal impediment to a prospect of teacher development, which leads to burnout (Yu, 2005). Consequently, inability to balance family and teaching demands with personal coping resources leads to burnout of married teachers (Braunstein-Bercovitz, 2013). In comparison, single teachers seem to benefit from this position, enjoying more liberty in personal development.

The above findings demonstrate both prevalence and complexity of this syndrome throughout nations. Every aspect of burnout as a psychological phenomenon depicts inconsistency in describing, identifying, preventing or treating it. Therefore, its nature asks for similar multidimensional and holistic approach in treatment. Although collection of data through selfreported questionnaires calls for caution in coming forth with explanations, still their self-perceptive aspect renders the relevant data valid to an extent. Future studies should focus on tracking and registering additional information such as, personality factors leading to burnout. More research should follow the route of studying social support and coping strategies of individuals (Burke, \& Greenglass, 1993). Longitudinal studies should also be used to track changes in the syndrome in relation to stressors at work, such as change in carrier, or additional job roles at workplace. However, future research should incorporate use of qualitative studies on burnout, which addresses the need for a personal approach to cases of burnout. Because of a limited research data available, the results presented here are of great significance to Kosovar teachers and society and create foundations on which future studies can build new strata of important information and new structures on Kosovar educational database. Identifying and analysing job burnout levels of teachers through this research, we hope to understand better how this syndrome affects teachers in Kosova, and find ways to alleviate it. Although our research addresses primarily a population of teachers, we hope that education stake holders, government officials, national teaching professionals and international educational and psychological experts can also benefit from findings of this study.

\section{References}

[1] Balcı, A. (2007). Sosyal Bilimlerde Araştırma Yöntem, Teknik ve Ilkeler (6th ed.). Ankara: Pegem Yayıncılık.

[2] Bauer, J., Stamm, A., Virnich, K., Wissing, K., Müller, U., Wirsching, M., Schaarschmidt, U. (2006). Correlation Between Burnout Syndrome and Psychological and Psychosomatic Symptoms Among Teachers. International Archives of Occupational and Environmental Health, 79, 199-204.

[3] Belcastro, P. A. (1982). Burnout and its Relationship to Teachers' Somatic Complaints and IInnesses. Psychological Reports, 50, 1045 - 1046.

[4] Braunstein-Bercovitz, H. (2013). A Multidimensional Mediating Model of Perceived Resource Gain, Work-Family Conflict Sources, and Burnout. International Journal of Stress Management, 20 (2), 95-115.

[5] Boles, J. S., Dean, D. H., Ricks, J. M., Short, J. C. \& Wang, G. (2000). The Dimensionality of the Maslach Burnout Inventory Across Small Business Owners and Educators. Journal of Vocational Behavior, 56, 12-34.

[6] Burke, R. J. \& Greenglass, E. (1989a). The Clients' Role in Psychological Burnout in Teachers and Administrators. Psychological Reports, 64, 1299-1306.

[7] Burke, R. J. \& Greenglass, E. R. (1989b). It May Be Lonely at the Top but it's less Stressful: Psychological Burnout in Public Schools. Psychological Reports, 64, 615-623.

[8] Burke, R. J. \& Greenglass, E. R. (1989c). Sex Differences in Psychological Burnout in Teachers. Psychological Reports, 65, 55-63.

[9] Burke, R. J. \& Greenglass, E. (1993). Work Stress, Role Conflict, Social Support, and Psychological Burnout Among Teachers. Psychological Reports, 73, 371-380.

[10] Büyüköztürk, Ş. (2010). Sosyal Bilimler Için Veri Analizi El Kitabı (11th ed.). Ankara: Pegem Yayıncılık.

[11] Byrne, B. M. (1991). Burnout: Investigating The Impact of Background Variables for Elementary, Intermediate, Secondary, And University Educators. Teaching \& Teacher Education, 7 (2), 197-209.

[12] Byrne, B. M. (1999). The Nomological Network of Teacher Burnout: A Literature Review and Empirically Validated Model. In a R. Vandenberghe, \& A. M. Huberman (Ed.). Understanding and Preventing Teacher Burnout: A Sourcebook of International Research and Practice. Cambridge: Cambridge University Press.

[13] Cano-Garcia, F. J., Padilla-Munoz, E. M. \& Carrasco-Ortiz, M. A. (2005). Personality and Contextual Variables in Teacher Burnout. Personality and Individual Differences, 38, 929-940. 
[14] Chang, M. (2013). Toward a Theoretical Model to Understand Teacher Emotions and Teacher Burnout in the Context of Student Misbehavior: Appraisal, Regulation and Coping. Motivation and Emotion, 37, 799-817.

[15] Chen, H., Wu, P. \& Wei, W. (2012). New Perspective on Job Burnout: Exploring the Root Cause Beyond General Antecedents Analysis. Psychological Reports, 110(3), 801-819.

[16] De Caroli, M. E. \& Sagone, E. (2012). Professional Self Representation and Risk of Burnout in School Teachers. Procedia - Social and Behavioral Sciences, 46, 5509-5515.

[17] Demerouti, E., Bakker, A. B., Nachreiner, F., \& Schaufeli, W. B. (2001). The Job Demands-Resources Model of Burnout. Journal of Applied Psychology, 86(3), 499-512.

[18] Demerouti, E. , Bakker, A. B., Nachreiner, F., \& Ebbinghaus, M. (2002). From Mental Strain to Burnout. European Journal of Work and Organizational Psychology, 11(4), 423-441.

[19] Doohan, H. (1982, winter). Burnout: A Critical Issue for the 1980s. Journal of Religion and Health, 21(4), 352358.

[20] Eisenstat, R. A. \& Felner, R. D. (1984). Toward a Differentiated View of Burnout: Personal and Organizational Mediators of Job Satisfaction and Stress. American Journal of Community Psychology, 12(4),411-431.

[21] Fernet, C., Guay, F., Senécal, C., \& Austin, S. (2012). Predicting Intraindividual Changes in Teacher Burnout: The Role of Perceived School Environment and Motivational Factors. Teaching \& Teacher Education, 28, 514525.

[22] Freudenberger, H. J. (1975, spring). The Staff Burn-out Syndrome in Alternative Institutions. Psychotherapy: Theory, Research and Practice, 12(1), 73-82.

[23] Gay, L. R. (1996). Educational Research. Florida: Prentice Hall.

[24] Gil-Monte, P. R. (2012). The Influence of Guilt on the Relationship Between Burnout and Depression. European Psychologist, 17(3), 231-236.

[25] Hultell, D., Melin, B. \& Gustavsson, J. P. (2013). Getting Personal with Teacher Burnout: A Longitudinal Study on the Development of Burnout Using a Person-based Approach. Teaching and Teacher Education 32, 75-86.

[26] Huston, J. (1989, Fall). Teacher Burnout and Effectiveness: A Case Study. Education, 110 (1).

[27] Köklü, N., Büyüköztürk, Ş., \& Bökeoĝlu, Ö. Ç. (2007). Sosyal Bilimler Için Istatistik (2nd ed.). Ankara: Pegem Yayıncilı.

[28] Korczak, D., Huber, B. \& Kister, C. (2010). Differential Diagnostic of the Burnout Syndrome. GMS Health Technology Assessment, 6.

[29] Korczak, D., Wastian, M., \& Schneider, M. (2012). Therapy of the Burnout Syndrome. GMS Health Technology Assessment, 8.

[30] Maslach, C. \& Jackson, S. E. (1981). The measurement of Experienced Burnout. Journal of Occupational Behaviour, 2, 99-113.

[31] Maslach, C., \& Jackson, S. E. (1985). The Role of Sex and Family Variables in Burnout. Sex Roles, 12 (7/8).

[32] Maslach, C. (1999). Progress in Understanding Teacher Burnout. In a R. Vandenberghe, \& A. M. Huberman (Ed.). Understanding and Preventing Teacher Burnout: A Sourcebook of International Research and Practice. Cambridge: Cambridge University Press.

[33] MASHT [Ministria e Arsimit, Shkencës dhe Teknologjisë] (2006, August). Plani Akcional i Punësimit të të Rinjve në Kosovë: Kornizë e Politikave Afatmesme 2006-2009 ( $3^{\text {rd }}$ ed.). Prishtinë: Qeveria e Republikës së Kosovës.

[34] MASHT (2011). Plani Strategjik i Arsimit në Kosovë 2011-2016. Prishtinë: Qeveria e Republikës së Kosovës.

[35] Montero-Marin, J., Garcia-Campayo, J., Mera, D. M., \& Del Hoyo, Y. L. (2009). A New Definition of Burnout Syndrome Based on Farber's Proposal. Journal of Occupational Medicine and Toxicology, 4 (31).

[36] Nagy, S., \& Nagy, M. C. (1992). Longitudinal Examination of Teachers' Burnout in a School District. Psychological Reports, 71, 523-531.

[37] Nenadović, M., Janković, Z., Katanić, M., Đokić-Pješčić, K., Malešević, Z., Radulović, S., Nenadović, N., \& Grbić, I. (2013). Burnout Syndrome. Praxis Medica, 42(1), 7-11.

[38] Ozan, M. B. (2009, Summer). A Study on Primary School Teacher Burnout Levels: The Northern Cyprus Case. Education, 129 (4).

[39] Rudow, B. (1999). Stress and Burnout in the Teaching Profession: European Studies, Issues, and Research Perspectives. In a R. Vandenberghe, \& A. M. Huberman (Ed.). Understanding and Preventing Teacher Burnout: A Sourcebook of International Research and Practice. Cambridge: Cambridge University Press. 
[40] Schaufeli, W. B., \& Enzmann, D. (1998). The Burnout Companion to Study \& Practice: A Critical Analysis. In a T. Cox, \& A. Griffiths (Ed.). London: Taylor \& Francis Ltd.

[41] Shirom, A., \& Melamed, S. (2006). A Comparison of the Construct Validity of Two Burnout Measures in Two Groups of Professionals. International Journal of Stress Management, 13(2), 176-200.

[42] Slinn, H. A. (2008). The Development and Performance of Professional Identity within a Resistance Culture: Kosovo-Albanian Teachers' Stories from the Conflict Years. (Unpublished doctoral dissertation). University of Sussex, Sussex.

[43] Author et al. (2012, December)[details removed for peer review]. Is There a Need for Councelling Psychology and Guidance Services in Kosova?. In B. Musaj (Eds.) Education for the Knowledge Society. Paper presented at $1^{\text {st }}$ Albania International Conference on Education (AICE), (pp. 622-627). Tiranë: Qendra për Arsim Demokratik (CDE).

[44] Van Horn, J. E., Schaufeli, W. B., Greenglass, E. R., \& Burke, R. J. (1997). A Canadian-Dutch Comparison of Teachers' Burnout. Psychological Reports, 81, 371-382.

[45] Williams, C. S. (2011, November/December). Combating Teacher Burnout Syndrome. The Journal, 10-11.

[46] Yu, S. (2005, November/December). Burnout in Higher Education "Two-Course" Teachers and Some Suggested Approached to the Problem. Chinese Education and Society, 38 (6).

[47] Zhong, N., \& Ling, H. (2014, June). Relationship Between Personality, Coping Style, and Job Burnout in Primary/Middle School Teachers. Chinese Journal of Clinical Psychology, 22(3), 525-529. 